\title{
The Impact of Manufactured Sand (M-Sand) as Partially and Fully Replacement of Fine Aggregate in Concrete
}

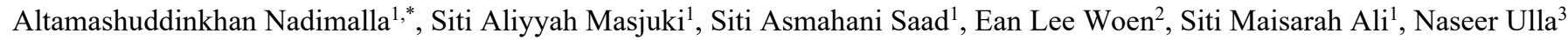 \\ ${ }^{1}$ Civil Engineering Department, International Islamic University Malaysia, 53100, Malaysia \\ ${ }^{2}$ Institute of Sustainable Energy, Universiti Tenaga Nasional, 43000, Malaysia \\ ${ }^{3}$ Civil Engineering Department, Bearys Institute of Technology, 574153, India
}

\begin{tabular}{l} 
A R T I C L E I N F O \\
\hline Article history: \\
Received: 23 November, 2019 \\
Accepted: 19 January, 2019 \\
Online: 27 January, 2020 \\
\hline
\end{tabular}

Keywords:

flexural test

Impact test

compression test

\begin{abstract}
A B S T R A C T
This, research work was to study the potential of $M$-sand as compared to river sand in concrete, here $M$-sand is replaced by river sand $0 \%, 45 \%, 50 \%, 55 \%$ and $100 \%$ in the concrete mix, Mix design is designed as per IS Standards. In this research a mix 1:2.32:2.82 (M20) was considered. The test specimen was casted for 7days, 28 days and 90days. The performance of $M$-sand was determined by several experiments such as slump test, impact strength test, flexural Strength, and compressive strength test. The results attained from each test states that as $M$-sand increases the slump value decreases. flexural strength, compressive strength and impact test of concrete at 7 days, 28 days and 90 days is greater at $100 \%$ and $50 \%$ replacement of $M$ sand by river sand.
\end{abstract}

\section{Introduction}

This paper is an extension of work originally presented in conference IEEE 5th International Conference on Engineering Technologies \& Applied Sciences, 22- 23 Nov 2018, Bangkok Thailand [1]. In the world, fine aggregate, probably natural sand, composes up to $30 \%$ of the volume of concrete, it is around 4 billion tons sand is required to meet annual necessity of concrete production [2]. Increasing in excavation of river sand from riverbeds leads to serious threat to environment [3]. Due to the limiting resources of river sand, alternatively $M$ sand can be used. [1]-[10]. The Manufactured sand is produced by crushing the rocks [5] [10].

The impact of M-Sand on the concrete properties:

Higher split tensile strength, higher compressive strength, \& higher flexural strength can be attained by the $50 \%$ substitution of of fine aggregate by M Sand [5], [6],[10]. It is due to the angular in shape of $\mathrm{M}$ sand gives good bonding between cement and aggregate. Gradual increase in strength can be obtained by $50 \%$ replacing river sand by $M$ sand. [4]. Gained higher strength at $60 \%$ by substituting the river sand by $\mathrm{M}$ sand at various proportions such as $0 \%, 20 \%, 40 \%, 60 \%$ and $80 \%$ [14]. The concrete flexural strength increased up to $2 \%$ and $4.3 \%$ by $25 \%$ and $100 \%$

"Corresponding Author: Altamashuddinkhan Nadimalla, Email: altamashk1987@gmail.com incorporation of river sand by $M$ sand[15]. Compared to the air curing and standard moist curing, the membrane curing will give the good strength in both river sand and M sand. Addition of Super Absorbent Polymer leads to a significant increase of mechanical properties of the concrete [16].

The $\mathrm{M}$ sand properties are very much similar to river sand so nowadays, instead of river sand, $M$ sand can be used in place of river sand[11], by utilizing $M$ sand in alternative of river sand the workability of concrete will decreases[12], the workability can be gained by adding water reducing admixtures [16].

It was observed that if river sand is completely replaced by $M$ sand, $\mathrm{M}$ sand has greater resistance to loss in strength as compared to river sand, if specimen is immersed in chemicals. The Combined replacement of $\mathrm{M}$ sand and Marble powder upto $25 \%$ by river sand increased the concrete strength [17].

Compressive strength increased by approximately $10 \%$ for 28 days of curing, when river sand fully substituted by $M$ sand [2]. It has been recorded that the compressive Strength enhance up to $50 \%$ incorporation of river sand by $\mathrm{M}$-sand sand and introduction of $2 \%$ to $6 \%$ waste plastics [18].

The $100 \%$ incorporation of natural sand by $\mathrm{M}$ sand, it helps in increase in paste volume as compare to river sand, which is useful to produce self-compacting concrete. Increase in paste volume is 
due presence of high fines in $M$ sand, which increases the water demand also [19].

Manufactured sand is suitable as alternative for river sand at affordable cost. It will act as cohesive cement mortar. It helps environment to maintaining the economical balance [3] [19].

\section{Objective}

- To inspect the properties of M-sand

- To examine the impact of M-sand on fresh and hard properties of concrete.

- To investigate the comparison of the, flexural Strength, compressive strength and Impact sstrength achieved by the cubes and beams in river sand and M-sand.

\section{Materials and Its Properties}

\subsection{Cement}

In this research Ordinary Portland Cement (53 grade) was used. As per IS: 8112-1989 Cement Properties are determined as tabulated in Table 1.

Table 1: Cement Properties

\begin{tabular}{|c|c|c|c|}
\hline \multicolumn{2}{|c|}{ Properties } & Result & $\begin{array}{c}\text { IS code } \\
\text { Requirement }\end{array}$ \\
\hline \multicolumn{2}{|c|}{ Specific gravity } & 3.05 & \\
\hline \multicolumn{2}{|c|}{ Standard consistency } & $31 \%$ & \\
\hline \multirow{3}{*}{ Setting time } & Initial(Minutes) & $33 \mathrm{~min}$ & 30 minimum \\
\cline { 2 - 4 } & Final(Minutes) & 380 & 600 maximum \\
& 7 min & \\
\hline \multirow{2}{*}{$\begin{array}{c}\text { Compressive } \\
\text { strength (MPa) }\end{array}$} & 28 days & 32 & 33 \\
\cline { 2 - 4 } & & 46 & 43 \\
\hline
\end{tabular}

\subsection{Fine Aggregates}

The river sand was collected from the Mangalore local area which is excavated from riverbeds. The sieve analysis of river sand is tabulated in Table 2 and shown in Figure 3.

Table 2: Sieve analysis of river sand

\begin{tabular}{|c|c|c|c|}
\hline $\begin{array}{c}\text { SL } \\
\text { No }\end{array}$ & $\begin{array}{c}\text { Sieve } \\
\text { Designation }\end{array}$ & $\begin{array}{c}\text { Percentage } \\
\text { Passing }\end{array}$ & $\begin{array}{c}\text { Grading Limits for Zone II } \\
\text { Sand (IS383) }\end{array}$ \\
\hline 1 & $4.75 \mathrm{~mm}$ & 99 & $90-100$ \\
\hline 2 & $2.36 \mathrm{~mm}$ & 87.8 & $75-100$ \\
\hline 3 & $1.18 \mathrm{~mm}$ & 54.6 & $55-90$ \\
\hline 4 & 600 micron & 37.6 & 35.59 \\
\hline 5 & 3000 micron & 12.6 & $8-30$ \\
\hline 6 & 150 micron & 6.4 & $0-10$ \\
\hline 7 & 75 micron & 2 & $0-10$ \\
\hline
\end{tabular}

From the sieve analysis test the river sand and M-sand fineness value are 3 and 3.45 respectively, both falls under zone2, it shows the M-sand properties is similar to river sand, M-sand is slightly coarser as compared to river sand. The sieve analysis of $\mathrm{M}$ sand is shown in Table 3 and Figure 4

Table 3: Sieve analysis of M- Sand

\begin{tabular}{|c|c|c|c|}
\hline $\begin{array}{c}\text { SL } \\
\text { No }\end{array}$ & $\begin{array}{c}\text { Sieve } \\
\text { Designation }\end{array}$ & $\begin{array}{c}\text { Percentage } \\
\text { Passing }\end{array}$ & $\begin{array}{c}\text { Grading Limits for Zone II } \\
\text { Sand (IS383) }\end{array}$ \\
\hline 1 & $4.75 \mathrm{~mm}$ & 100 & $90-100$ \\
\hline 2 & $2.36 \mathrm{~mm}$ & 91 & $75-100$ \\
\hline 3 & $1.18 \mathrm{~mm}$ & 61.2 & $55-90$ \\
\hline 4 & 600 micron & 48.3 & 35.59 \\
\hline 5 & 300 micron & 27.4 & $8-30$ \\
\hline 6 & 150 micron & 13.8 & $0-10$ \\
\hline 7 & 75 micron & 3.8 & $0-10$ \\
\hline
\end{tabular}

\subsection{Coarse Aggregate}

The $20 \mathrm{~mm}$ down size crushed stone is used in this research. Table 4 and Figure 5 shows the Coarse aggregate sieve analysis.

Table 4: Sieve analysis of Coarse Aggregate

\begin{tabular}{|c|c|c|c|c|}
\hline $\begin{array}{l}\text { SL } \\
\text { No }\end{array}$ & $\begin{array}{c}\text { Sieve } \\
\text { Designation }\end{array}$ & $\begin{array}{c}\text { Percentage } \\
\text { Passing }\end{array}$ & $\begin{array}{c}\text { Gradation } \\
\text { requirement as } \\
\text { per IS } 383-1970 \\
\text { for grade II } \\
\end{array}$ & Remark \\
\hline 1 & 40 & 100 & 100 & \multirow{4}{*}{$\begin{array}{l}\text { As per IS } \\
383 \text { the } \\
\text { sample } \\
\text { confirms } \\
\text { the graded } \\
\text { aggregate }\end{array}$} \\
\hline 2 & 20 & 98 & $95-100$ & \\
\hline 3 & 10 & 46 & $25-50$ & \\
\hline 4 & 4.75 & 0.8 & $1-10$ & \\
\hline
\end{tabular}

\subsection{Mix Design}

In this research work a mix design 1:2.32:2.82 ( M20) is considered.

Table 5: Mix Design

\begin{tabular}{|c|c|c|c|c|c|}
\hline \multirow{2}{*}{$\begin{array}{c}\text { Mix } \\
\text { Design }\end{array}$} & $\begin{array}{c}\text { Cement } \\
\left(\mathbf{k g} / \mathbf{m}^{\mathbf{3}}\right)\end{array}$ & \multicolumn{2}{|c|}{$\begin{array}{c}\text { Aggregate } \\
\left(\mathbf{k g} / \mathbf{m}^{\mathbf{3}}\right)\end{array}$} & \multirow{2}{*}{$\begin{array}{c}\text { w/c } \\
\text { Ratio }\end{array}$} & (l) \\
\cline { 3 - 4 } & & Fine & Coarse & & \\
\hline $1: 2.32: 2.82$ & 358 & 829.67 & 1009.96 & 0.55 & 197 \\
\hline
\end{tabular}

\section{Fresh Properties of Concrete}

\subsection{Slump test}

The workability of concrete was estimated by using slump test. Figure 6 and Table 6 shows that slightly decrease in the slump value as $\mathrm{M}$ sand increases. 


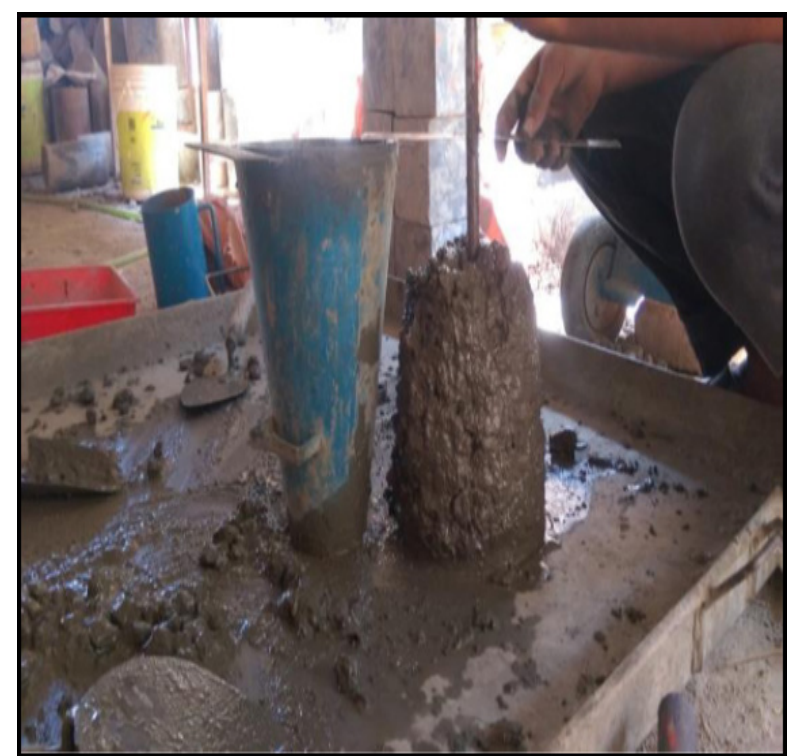

Figure 1: Slump test

Table 6: Slump test

\begin{tabular}{|c|c|}
\hline Percentage of M Sand & Slump Value (mm) \\
\hline $0 \%$ & 102 \\
\hline $45 \%$ & 100 \\
\hline $50 \%$ & 99 \\
\hline $55 \%$ & 100 \\
\hline $100 \%$ & 99 \\
\hline
\end{tabular}

\section{Hard properties of Concrete}

\subsection{Compressive Strength test}

The tests were carried out on $150 \mathrm{~mm} * 150 \mathrm{~mm} * 150 \mathrm{~mm}$ size of cubes. The outcomes is displayed in Figure 8.

Figure 8 shows the compressive strength for results for 7 days, 28 days and 90 days curing, it is detected that the compressive strength increased for $100 \%$ and $55 \%$ of replacement of M Sand by river sand, $100 \%$ and $55 \%$ incoporation of $\mathrm{M}$ sand can be advised to use as fine aggregate.

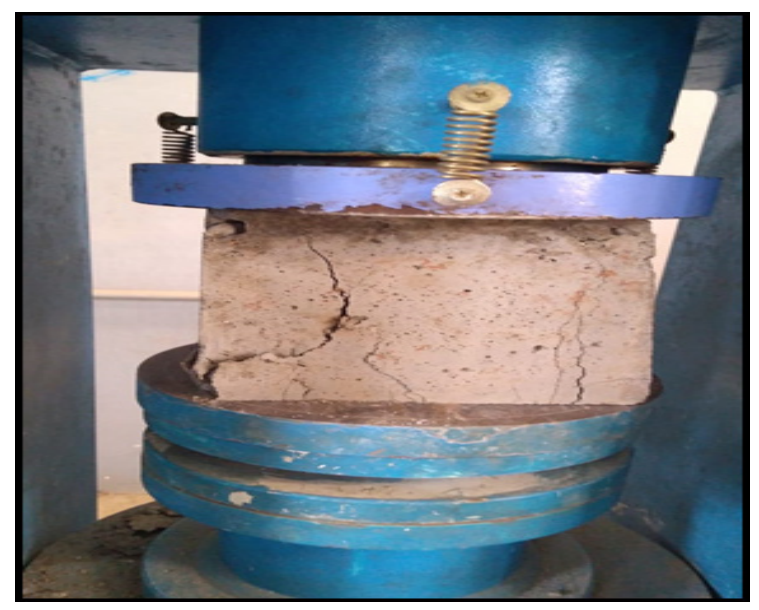

Figure 2: Compressive strength test

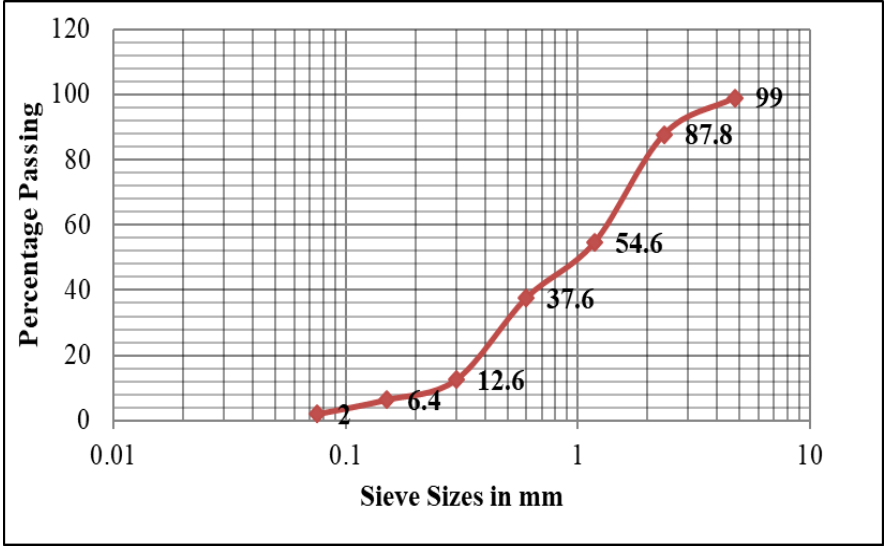

Figure 3: Sieve analysis of River Sand

\subsection{Flexural strength test}

The tests were carried out on beams of width $150 \mathrm{~mm}$ length $150 \mathrm{~mm}$ and $70 \mathrm{~mm}$ thickness. Figure 9 shows the flexural strength for results 7 days, 28 days and 90 days curing, it is observed that the flexural strength increased for $100 \%$ and $55 \%$ of incorporation of M Sand by river sand, $100 \%$ and $55 \%$ incorporation of M sand can be advised to use as fine aggregate.

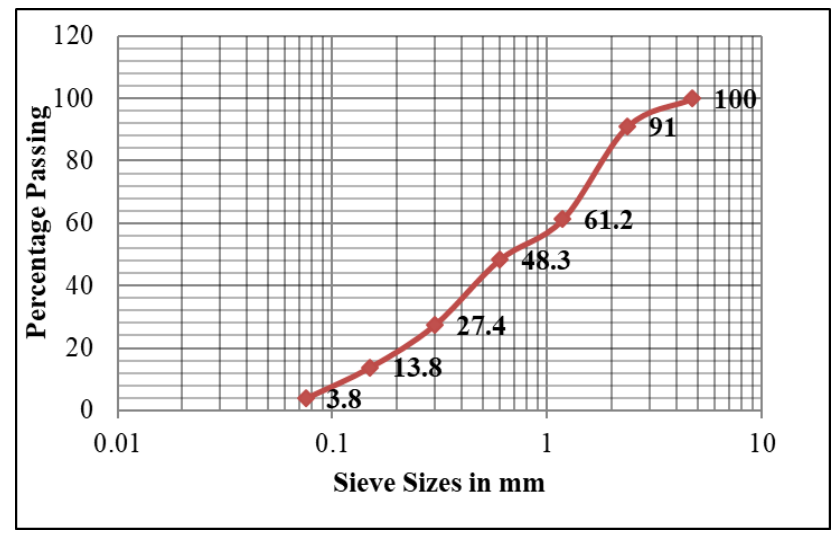

Figure 4: Sieve analysis of M Sand

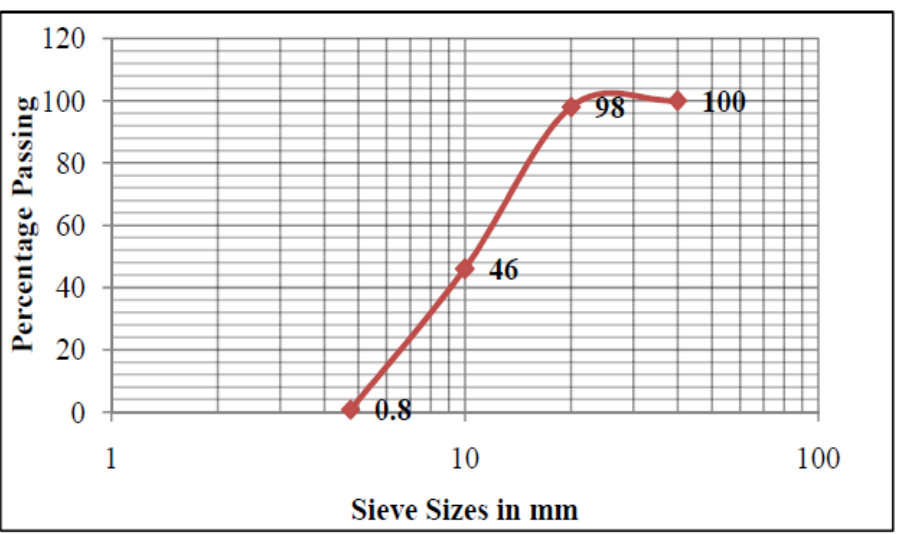

\subsection{Impact Test Results}

Figure 10 shows the variation in impact test results of the concrete specimen prepared by replacing natural sand by M-sand at the percentages of $0 \%, 45 \%, 50 \%, 55 \%$ and $100 \%$. Results shows that energy consumption in $55 \%$ and $100 \%$ replacement 
shows increase in energy consumption that is about $47.99 \%$ and $40 \%$ for initial crack, $48.38 \%$ and $38.7 \%$ for ultimate failure when compare to $0 \%$ replacement. It can be concluded that $100 \%$ and $55 \%$ substitution of river sand by $\mathrm{M}$ sand has a threshold values for an optimal performance in energy adsorption and crack resistance.

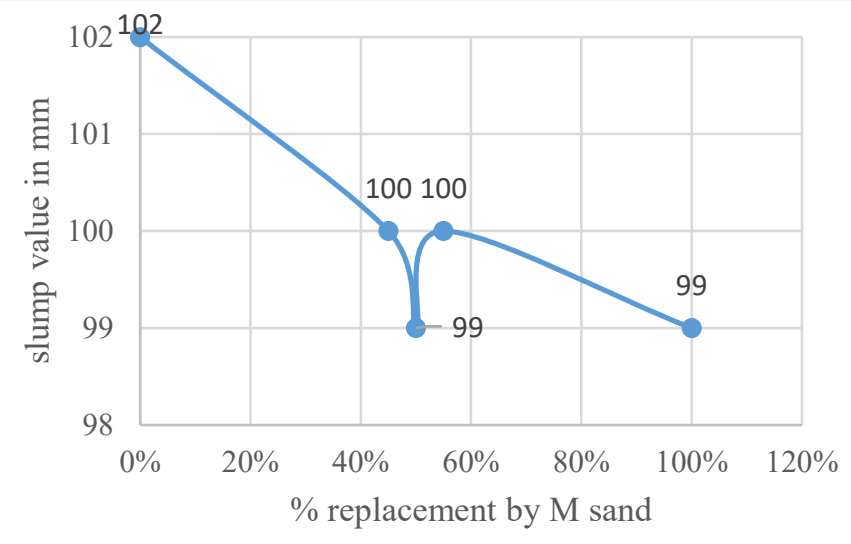

Figure 6: Slump test graph

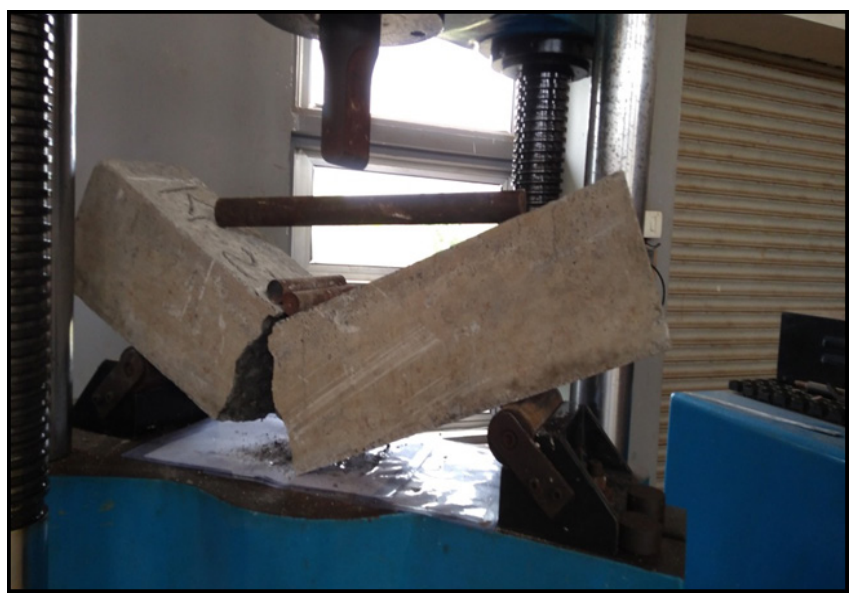

Figure 6: Flexural strength test

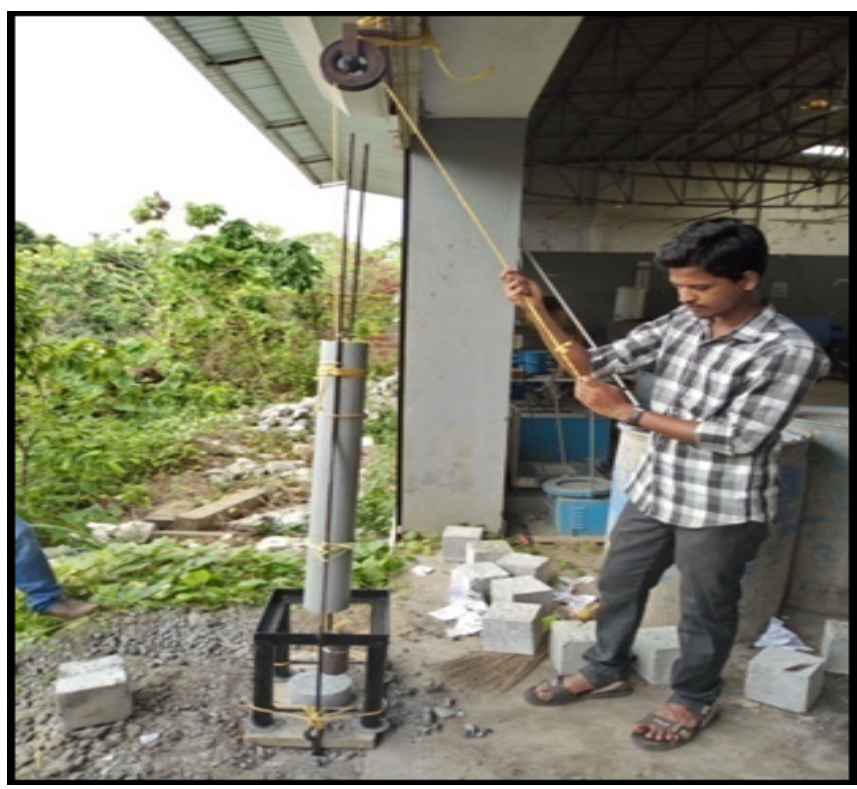

Figure 7: Impact test on concrete

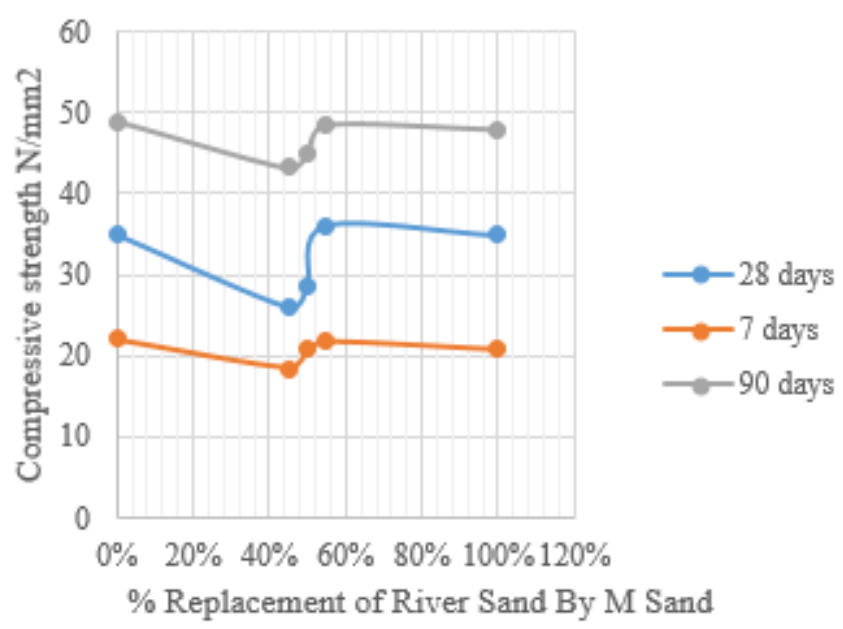

Figure 8: Compressive strength test graph
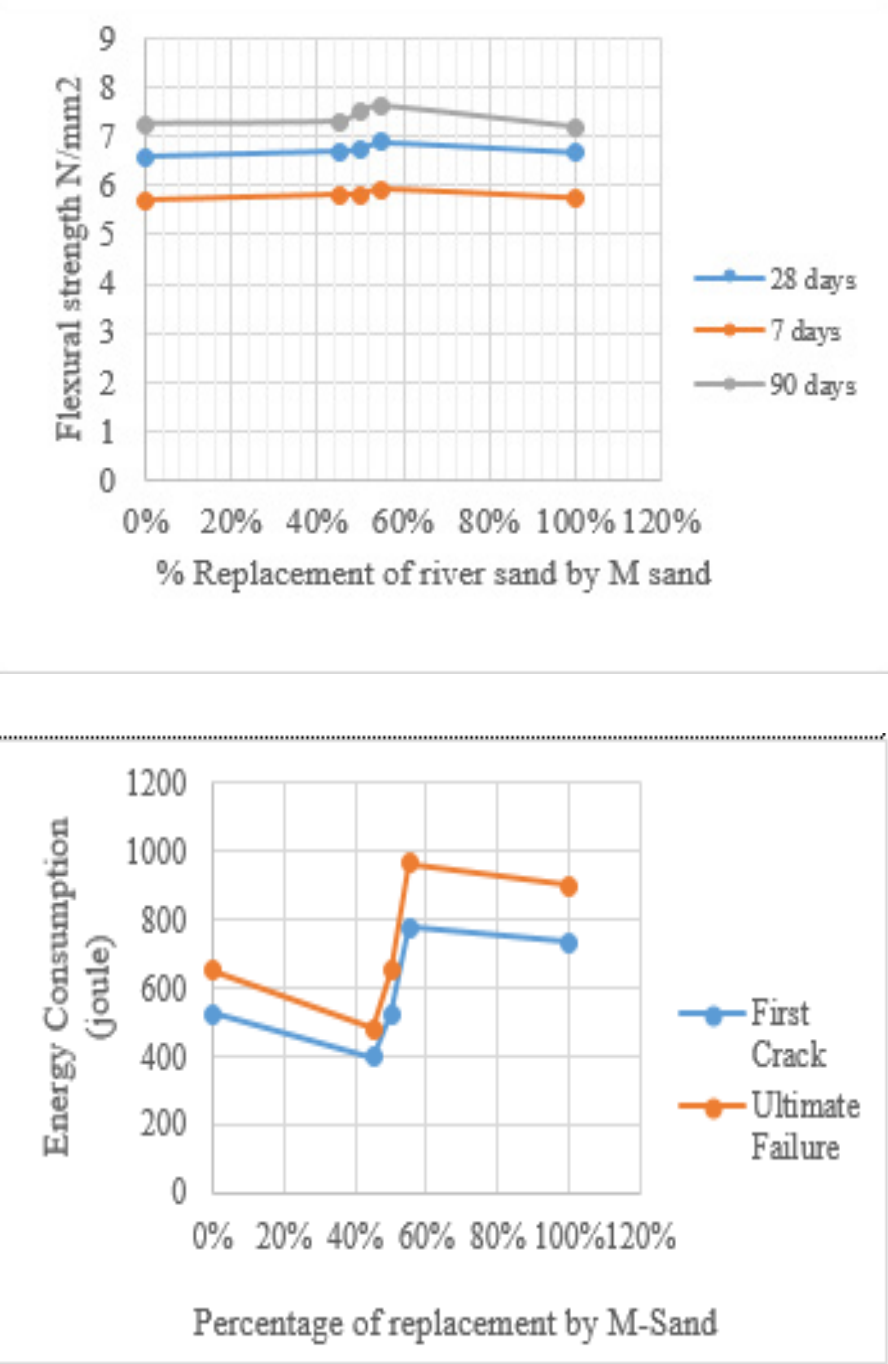

Figure 10: Variation in Energy Consumption for M20 grade Concrete Specimen

\section{Conclusion}

M-sand and River sand fineness value are 3 and 3.45 respectively, both falls under zone-2, it shows the M-sand 
properties is similar to river sand, M-sand is slightly coarser as compared to river sand.

By $100 \%$ and $55 \%$ incorporation of $\mathrm{M}$ sand by river sand concrete can achieve higher flexural strength and compressive strength of concrete at 7 days, 28 days and 90 days.

Concrete can achieve optimal performance in energy adsorption and crack resistance by $100 \%$ and $55 \%$ substitution river sand by M-sand.

An incorporation of $100 \%$ and $55 \%$ of $\mathrm{M}$ sand can be advised to use as fine aggregate to enhance the strength of Concrete.

\section{Acknowledgement}

The authors would like to acknowledge financial support from iRMC Bold2025, Universiti Tenaga Nasional, Malaysia.Grant Code: RJO 10436494.

\section{References}

[1] Altamashuddunkhan, N., \& Siti Alliyah, M, "The Effect of Replacement of Natural Sand by Manufactured Sand on the Properties of the Concrete. 2018 IEEE 5th International Conference on Engineering Technologies and Applied Sciences (ICETAS)", 22-23, 2018. DOI: 10.1109/ICETAS.2018.8629206

[2] A. Zimar, G. Samarawickrama, W. Karunarathna, and S. Jayakody, "Effect of Manufactured Sand as a Replacement for Fine Aggregates in Concrete," 8th Int. Conf. Struct. Constr. Manag., no. October 2017.

[3] P. A. Jadhav and D. K. Kulkarni, "Effect of replacement of natural sand by manufactured sand on the properties of cement mortar," vol. 3, no. 3, pp. 621$628,2013$.

[4] G. Nithyambigai and F. Ash, "Partial Replacement of Manufactured Sand and Fly Ash in Concrete," vol. 5, no. 6, 2015.

[5] K. U. Mani, N. Sathya, and R. Sakthivel, "International Journal of Modern Trends in Engineering and Research Effect of replacement of River sand by M-sand in high strength concrete," 2014

[6] R. N. U. Shanmugapriya T., "Optimization of Partial Replacement of M-Sand By Natural Sand in High Performance Concrete With Silica Fume," Int. J. Eng. Sci. Emerg. Technol., vol. 2, no. July, pp. 73-80, 2012.

[7] N. R. Monika and S. Sarankokila, "Partial Replacement of M-Sand on Concrete by Self Curing and Standard Curing Method," pp. 12162-12169, 2015. DOI:10.15680/IJIRSET.2015.0412087

[8] T.Subramani \& K.S.Ramesh, " Experimental Study on Partial Replacement of Cement With Fly Ash And Complete Replacement of Sand With M sand," Int. J. Appl. or Innov. Eng. Manag., vol. 4, no. 5, pp. 313-322, 2015.

[9] A. Jayaraman, "Experimental Study on Partial Replacement of Natural Sand with M- Sand and Cement with Lime Stone Powder," vol. 6, no. 2, pp. 948954, 2014.

[10] T. F. Kala, P. Asha, and S. Elavenil, "Properties of Concrete using Manufactured Sand as Fine Aggregate," Int. J. ChemTech Res., vol. 11, no. 03, pp. 94-100, 2018. DOI: http://dx.doi.org/10.20902/IJCTR.2018.110337

[11] M. Meghashree, "Comparison of Physical Properties between Natural Sand and Manufactured Sand," vol. 3, no. 07, pp. 92-96, 2016.

[12] S. Suresh and J. Revathi, "Effect of M-Sand on Setting Time of High Performance Concrete," Asian J. Res. Soc. Sci. Humanit., vol. 6, no. 10, p. 1648, 2016. DOI:10.5958/2249-7315.2016.01118.7

[13] P. Jaishankar and K. Saravana Raja Mohan, "Experimental investigation on nano particles in high performance concrete," Int. J. ChemTech Res., vol. 8, no. 4, pp. 1666-1670, 2015.

[14] Y. Boopathi and J.Doraikkannan, "Study on M-Sand as a Partial Replacement of Fine Aggregate In Concrete," Int. J. Adv. Res. Trends Eng. Technol. vol. 3, no. 2, pp. 746-749, 2016.

[15] B. K. Meisuh, C. K. Kankam, and T. K. Buabin, "Effect of quarry rock dust on the flexural strength of concrete," Case Stud. Constr. Mater., vol. 8, no. July 2017, pp. 16-22, 2018. DOI: https://doi.org/10.1016/j.cscm.2017.12.002

[16] J. R. Sagura R, "Experimental Study on Mechanical Properties of M-Sand Concrete by Different Curing Methods.," IOSR J. Mech. Civ. Eng., vol. eISSN: 22, pp. 19-25.

[17] M. Idrees, " Utilization of Waste Quarry Dust And Marble Powder in Concrete," no. July, 2019.

[18] B. Bahoria, D. K. Parbat, P. B. Nagarnaik, and U. P. Waghe, "Effect of replacement of natural sand by quarry dust and waste plastic on compressive
\& split tensile strength of M20 concrete," Procedia Eng., no. March, p. 9, 2013.

[19] P. Nanthagopalan and M. Santhanam, "Fresh and hardened properties of selfcompacting concrete produced with manufactured sand," Cem. Concr. Compos., vol. 33, no. 3, pp. 353-358, 2011.

DOI: https://doi.org/10.1016/j.cemconcomp.2010.11.005 